\title{
sciendo
}

DOI 10.2478/sbe-2020-0012

SBE no. 15(1) 2020

\section{THE ROLE OF PARTNERSHIPS IN THE DEVELOPMENT OF THE SHORT CHAINS OF ORGANIC HONEY DISTRIBUTION}

\author{
NICULA VIRGIL \\ Lucian Blaga University of Sibiu, Romania \\ SPÂNU SIMONA \\ Lucian Blaga University of Sibiu, Romania
}

\begin{abstract}
:
The bees were declared the most important living beings on the planet. They act as natural indicators of the state of the environment, protect and maintain ecosystems and contribute to genetic and biotic diversity. Due to its socio-economic and scientific role, beekeeping is an activity that contributes to the development of the rural area. In the analysis we have chosen Hunedoara County, considering its national position and prospects for the development of organic beekeeping. The elaboration of the PESTEL analysis ensures a long-term perspective of the apiculture strategy in Hunedoara County. In order to dispose of bee products (honey, organic honey, pollen, propolis, etc.) in optimal conditions to be marketed both through stores and online, we propose the creation of short chains between a specialized micro-enterprise, tourist pensions that provides food services, restaurants or bars that are located in areas with commercial ford and local beekeeping producers in HNV areas, of which at least one holds certification for organic honey. Beekeeping entrepreneurship can be developed through the actions of beekeepers in the field of promotion, by efficiently selecting possible distribution channels in the country and abroad.
\end{abstract}

Key words: Sustainable development, Partnership, Short distribution chains, Organic honey

\section{Introduction}

As an integral part of European agriculture, the beekeeping sector is being the main source or one of the additional sources of income for approx. 606,000 EU citizens, managing over 17.5 million hives in the EU. The importance of this sector is much greater than results from its contribution to the gross domestic product, given that $84 \%$ of plant species and $76 \%$ of food production in Europe depend on pollination by bees, so that the economic value product, estimated at EUR 14.2 billion per year in the EU, is much higher than the value of honey produced (http://apimondia.com/documents/apimondia).

The beekeeping sector is crucial for agriculture and biodiversity in general (Bogdanov S., 2009), which is why EU co-financing for the beekeeping sector has 
increased from $€ 120$ million to $€ 180$ million for beekeeping programs in the period 20172019, according to the report on program implementation from the EU. The significance of honey for maintaining ecological balance and biodiversity is special (Napolitano G., 2006). Currently, the importance of pollination is not properly appreciated and is underestimated in the EU, while in the US $\$ 2$ billion is spent annually on artificial pollination. The situation of beekeepers currently active in the EU is far from easy, with many factors which hinder their activity. The biggest problem is by far the spread of counterfeit honey on the domestic market, which is responsible for halving the purchase price of honey in 2016 compared to 2014, especially in the main honey producing countries, such as Romania, Bulgaria, Spain, Portugal, France, Croatia and Hungary (http://apimondia.com/documents/apimondia).

Due to its socio-economic and scientific role, beekeeping is an activity that contributes to the development of the rural area (Qaiser T., Ali M., Taj S., 2013). In recent years, the EU has implemented support programs and policies for beekeepers. These measures took into account the problems that European beekeepers face, namely the massive loss of bee colonies, the costs of production for honey and the fierce competition on the market. The main objectives of these programs were to improve the production conditions and ensure the marketing of bee products (Ignjatijević Svetlana and all, 2018). Support programs include technical assistance (training courses), measures to combat varicose veins and streamline transhumance, and support for honey analysis and applied research (http://ec.europa.eu/ agriculture/honey/index ro).

The community and national financial support granted in the beekeeping sector (MADR Activity Report, 2019) was granted according to the National Beekeeping Program elaborated by the Ministry of Agriculture and Rural Development together with the representatives of the professional beekeeping organizations, for a period of 3 years, respectively 2017-2019 and aimed at improving the conditions of production and marketing of bee products (http://www.madr.ro/programul-national-apicol.html).

\section{Honey production at global, European and national level}

With a production of around 250000 tonnes/year (Purnhagen K., 2016), the EU is the second largest producer of honey after China (Ramadani V., and all, 2019). The EU does not produce enough to cover its own honey consumption. EU honey production increased slightly, with annual variations depending on the climatic conditions. However, maintaining the current level of production may become more difficult for beekeepers because of the challenges they face in terms of bee health and habitat loss as a result of intensified agricultural practices.

According to the European Commission Report on the implementation of measures on the beekeeping sector (Nicolae Simona, 2010), honey production in the EU was 240,000 tonnes in 2014 and increased to 268,000 tonnes in 2015. With a production of approx. 20,000 tonnes, Romania ranked fifth in 2014, after Estonia, Hungary, Greece and Poland, and in 2015 it ranked first in the EU, with a production of 35,000 tonnes. The number of hives has increased steadily in Romania, from 975,000 in 2008-2010, to $2,834,000$ in 2016. Our country recorded the highest growth rate in the EU, in 2014-2016, respectively $59.5 \%$. At the EU level there was an increase of $9.5 \%$ in the same period, 
from 15,704 to 17,189 hives; in Poland by $17.5 \%$, from 1281 to 1505 ; in Hungary with $8.8 \%$, from 1089 to 1184 hives and so on.

According to Eurostat data for the period 2017-2019, in Europe there were about 606,000 beekeepers, but their number is decreasing, compared to 631,236 in the period 2014-2016. In Romania, the number of beekeepers decreased from 43,200 persons to 22,930 during the reference periods; in France from 75000 to 41560 ; there are also countries where the number has increased, such as: Poland from 51,778 to 62,575, or Germany from 98,297 to 116,000 . Many beekeepers leaving the sector, for reasons related to age, are not replaced by other younger beekeepers. The situation is different in the Member States. The German Beekeepers Association gave priority to a strategy for recruiting beekeepers and provided courses for beginners, which led to an increase in the number of active beekeepers. Some of these actions were financed through the "technical assistance" measure provided for in the European programs.

The EU is the world's leading importer of honey. Imports into the EU increased year by year. In 2015, the EU imported about 200,000 tonnes of honey, amounting to 498,027 thousand euros, representing almost $75 \%$ of the total EU production volume, compared to 141,357 tonnes in 2008 . Half of these imports came from China $(75,142$ tonnes) followed by Ukraine (36,742 tons), Argentina (28,061 tons) and Mexico (20,058 tons). Honey imported from third countries is much cheaper than honey produced in the EU. In 2015, the average unit import price for honey from China was 1.64 euros $/ \mathrm{kg}$, and the average EU price of wholesale honey sold in bulk was 3.78 euros/kg. Due to higher production costs, EU producers cannot compete with honey imports. Given that 2016 was a difficult year for beekeepers in EU countries, the amount of imported honey did not exceed that of the previous year.

The prices of honey vary significantly depending on the quality and the point of sale. In the case of polyfloral honey, at the level of 2017, prices ranged from 2.54 euros/ $\mathrm{kg}$ in Poland for polyphlorous honey sold in bulk to 15.18 euros / kg for honey sold at the production site in the United Kingdom. The quality of imported honey is below that of Romanian honey or other EU member countries. This is reflected by the low price paid per $\mathrm{kg}$ of honey by importing countries. The exception is New Zealand honey, whose price reflects the very good quality of the product. In contrast, honey exported by EU countries has a significantly higher price, proof of product quality. Exports from the EU are negligible compared to imports.

According to the data provided by the official statistics, the year 2017 was one with record production, against the favourable weather conditions when it stood at 13,434 tonnes, according to the reports of the Ministry of Agriculture. The total value of the market amounts to about 37.5 - 40 million dollars.

Currently there are over 80,000 producers, of which the vast majority is made up of natural persons and 26 processors. Of the more than 1.6 million bee families, only 6,000 remain in the state sector, the rest belonging to private producers. The beekeeping sector has received state support: in 2018, they were allocated up to the limit of 60 billion Lei, 100,000 lei for each family of bees, provided that the producer delivers 10 kilos of honey to the processors. In 2019, the grant allocated from the budget was 20 billion lei. One farm holds on average 22 bee families. On the external market, one tonne of acacia honey 
reaches 3000 Euro, and one polyphlorous honey at 2100 Euro, while on the domestic market the prices are, at the purchase, about 80 million lei/ton. Domestic production is mainly dominated by polyphloric honey $(60 \%)$, followed by acacia $(30 \%)$ and linden $(10 \%)$.

Table 1: Evolution of honey production (tonnes) at national and regional level (20152018)

\begin{tabular}{|c|c|c|c|c|}
\hline \multirow{2}{*}{$\begin{array}{l}\text { Total nationally and by } \\
\text { development regions }\end{array}$} & \multicolumn{4}{|c|}{ Period } \\
\hline & 2015 & 2016 & 2017 & 2018 \\
\hline $\begin{array}{l}\text { Total, of which } \\
\text { - in the private sector } \\
\text { - in individual farms }\end{array}$ & $\begin{array}{l}27893 \\
27883 \\
27787\end{array}$ & $\begin{array}{l}21202 \\
21194 \\
21072\end{array}$ & $\begin{array}{l}30177 \\
30168 \\
30069\end{array}$ & $\begin{array}{l}29162 \\
29152 \\
29046\end{array}$ \\
\hline $\begin{array}{l}\text { North - West region, of which } \\
\text { - in the private sector } \\
\text { - in individual farms }\end{array}$ & $\begin{array}{l}3568 \\
3658 \\
3556\end{array}$ & $\begin{array}{l}2821 \\
2821 \\
2808\end{array}$ & $\begin{array}{l}4031 \\
4031 \\
4021\end{array}$ & $\begin{array}{l}4249 \\
4249 \\
4235\end{array}$ \\
\hline $\begin{array}{l}\text { Center region, from which } \\
\text { - in the private sector } \\
\text { - in individual farms }\end{array}$ & $\begin{array}{l}4269 \\
4269 \\
4236\end{array}$ & $\begin{array}{l}3117 \\
3117 \\
3099\end{array}$ & $\begin{array}{l}3829 \\
3829 \\
3813\end{array}$ & $\begin{array}{l}3493 \\
3493 \\
3474\end{array}$ \\
\hline $\begin{array}{l}\text { North - East region, from which } \\
\text { - in the private sector } \\
\text { - in individual farms }\end{array}$ & $\begin{array}{l}4081 \\
4074 \\
4054\end{array}$ & $\begin{array}{l}3188 \\
3181 \\
3157\end{array}$ & $\begin{array}{l}3917 \\
3909 \\
3893\end{array}$ & $\begin{array}{l}3880 \\
3873 \\
3857\end{array}$ \\
\hline $\begin{array}{l}\text { South - East region, of which } \\
\text { - in the private sector } \\
\text { - in individual farms }\end{array}$ & $\begin{array}{l}3271 \\
3269 \\
3208\end{array}$ & $\begin{array}{l}2232 \\
2232 \\
2196\end{array}$ & $\begin{array}{l}5201 \\
5201 \\
5174\end{array}$ & $\begin{array}{l}4724 \\
4723 \\
4697\end{array}$ \\
\hline $\begin{array}{l}\text { South Region - Muntenia, from which } \\
\text { - in the private sector } \\
\text { - in individual farms }\end{array}$ & $\begin{array}{l}4058 \\
4057 \\
4045\end{array}$ & $\begin{array}{l}3116 \\
3115 \\
3104\end{array}$ & $\begin{array}{l}4049 \\
4048 \\
4034\end{array}$ & $\begin{array}{l}3962 \\
3961 \\
3944\end{array}$ \\
\hline $\begin{array}{l}\text { Bucharest - llfov region, of which } \\
\text { - in the private sector } \\
\text { - in individual farms }\end{array}$ & $\begin{array}{l}277 \\
277 \\
276\end{array}$ & $\begin{array}{l}193 \\
193 \\
191\end{array}$ & $\begin{array}{l}261 \\
261 \\
257\end{array}$ & $\begin{array}{l}344 \\
344 \\
342\end{array}$ \\
\hline $\begin{array}{l}\text { West region, from which } \\
\text { - in the private sector } \\
\text { - in individual farms }\end{array}$ & $\begin{array}{l}3712 \\
3712 \\
3705\end{array}$ & $\begin{array}{l}2726 \\
2726 \\
2718\end{array}$ & $\begin{array}{l}3590 \\
3590 \\
3583\end{array}$ & $\begin{array}{l}3124 \\
3123 \\
3118\end{array}$ \\
\hline
\end{tabular}

Source: data processed insse.ro, Tempo online database, 2019

Due to the fact that the domestic consumption does not exceed $500 \mathrm{gr} . / \mathrm{an} / \mathrm{capita}$, and in the European Union the value of 2 kilograms is reached, more than $90 \%$ of the Romanian honey can be allocated to the export. Romania ranks fourth in the European Union in honey production. From a single hive, annually, a beekeeper gets 10 kilograms of honey, be it acacia, polyfloral or sunflower honey. Of the more than 12,249 tonnes exported in 2018, 80\% of honey arrived in European countries. In the first place is Germany with $38 \%$ of the quantity, followed by Italy with $19 \%$. Of the obtained production, $90 \%$ reaches authorized processors, and $10 \%$ is sold directly.

\section{Research methodology}

The motivation of choosing honey and bee products is based on three needs of the current consumer society, namely: the need to find the true taste of consumed products, that specific taste of authentic products, that natural flavour that the products marketed by the big chains of processors and distributors don't have it; the need to consume healthy products, which brings in more nutrients and vitamins and does not 
contain additions with negative impact on the body; the need to consume honey and derived bee products that are authentic and/or eco-certified, from a secure and traceable source (IFOAM, 2014).

In the analysis we have chosen the county of Hunedoara, considering its positioning at national level and the prospects for the development of ecological beekeeping. The elaboration of the PESTEL analysis is necessary in order to have a longterm perspective and to clarify the strategic opportunities and threats faced by the beekeeping activity in Hunedoara County. The political, economic, social, ecological and legislative factors were analysed. Based on the detailed analysis of the situation of each factor, taking into account its level or importance, it is appreciated the influence they exert on the overall activity of the Hunedoara beekeeping and the degree of performance achieved within the sphere of that factor (Nicula V., Spânu Simona, 2019).

The extensive investigation of the main aspects required by the PESTEL diagnostic analysis concerning beekeeping activity in Hunedoara County it is oriented in particular to the strong points and major weaknesses, which have a significant influence on the evolution of beekeeping and its economic performance. However, under certain economic conditions the weaknesses that should not be underestimated because they can have a major influence on the situation of beekeeping in the area. The method materializes in recommendations on the sustainable development of the analysed sector (for the recovery of strengths and opportunities) or corrective (for eliminating or mitigating weaknesses and identified threats).

\section{PESTEL diagnostic analysis on beekeeping activity in Hunedoara County}

Concretely, the structuring in four steps of the diagnostic analysis imply: the analysis of the external environment that enables highlighting the opportunities and restrictions it offers to the beekeeping activity in Hunedoara County, the analysis of the competence that highlights the strengths and weaknesses; the establishment of a system of management values in beekeeping that assume the analysis of the mission, objectives, performance levels that the activity in the beekeeping sector aims to achieve and, finally, the analysis of the internal environment.

From the analysis of the micro-environment of Hunedoara, it is highlighted that only a small quantity, of less than $25 \%$ of the honey produced in Hunedoara County, finds its own market in the country, a situation that has remained in these quotas for several years. About one third of the 300 tons of honey produced annually in the county is capitalized through the collection and marketing system administered by the trading company Apicola SRL. Of this quantity, $80 \%$ is exported to Germany. There is no higher demand on the local market, although prices for honey and bee products are affordable. Honeymoon beekeepers' honey is of very good quality, which is why Germany buys large quantities, given that the competition on the European market is very high. The advantage of the Honeycomb Honey is not the price, because at the price level the competition from China and Ukraine is impossible to counter. At the wholesale purchase, the price for the honey in Romania is around 12 lei/kg, when Ukraine sells it for 6 lei/kg and China for about $4.5 \mathrm{lei} / \mathrm{kg}$, i.e. less than one euro/kg. But even under these conditions, the Germans prefer 
to pay more for premium quality honey. However, this forces rigor in the selection of honey purchased. Apicola SRL exports to Germany only premium quality honey and the organic one are increasingly seeking. Annually, about 80 tons of the best quality honey is exported from Hunedoara to Germany.

Customers of shops specialized in the marketing of bee products are those who have become accustomed to buying from the same places, generally elderly people for whom online shopping is not available (Borza Anca et all, 2009). But an online store could attract young customers, for whom leisure time is too precious to spend on shopping (Coughlan A. T., et all, 2005).

The biggest competition for a newly established company (a partnership for the implementation of a short distribution chain) is represented by the Apicola store in Deva, which sells the honey of the associated beekeepers. The turnover of the company Apicola $\mathrm{SRL}$ records significant increases from one year to another and has loyal customers through the quality of the products, the professionalism of those who sell the products and the affordable prices they practice.

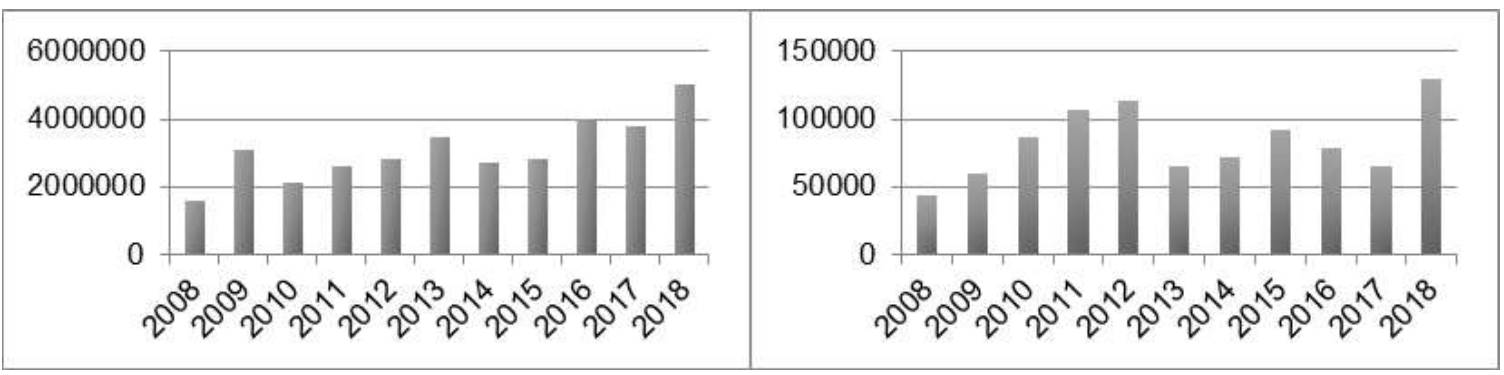

Fig. 1. Evolution of turnover and profit (lei) from Apicola SRL in the period 2008-2018 Source: Apicola processed internal data

The PESTEL analysis allows the understanding of whole picture of the circumstances in which the Hunedoara beekeeping works, which facilitates maximizing of the opportunities and minimizing the threats that the activities in the field meets. When such strategic planning is done on correct bases, it provides a strong groundwork for future progress.

Political factors can influence the beekeeping of Hunedoara by regulating the arrangement of fly markets or separate spaces in the existing agro-food markets in urban areas where traditional local certified products are exposed for sale (http://www.afir.info). In this way, local producers of honey and bee products will be encouraged to keep the traditional recipes, and urban consumers will have the opportunity to choose good quality products and contribute to the growth of local pride. It is also an opportunity for economic development for rural areas and even for increasing the interest in preserving traditions and authenticity. In this respect, in August 2018, the financing of the projects was launched by Sub-measure 3.1 "Support for the first time participation in quality schemes" (www.afir.info) of the National Rural Development Program 2014 - 2020, which is granted to the legally constituted farmers and farmers groups participating for the first given to a quality scheme of the European In addition, the National Institute for Research and Development for Food Bio resources - IBA Bucharest offers assistance and training 
courses free of charge to eligible companies in fields such as food and beverage processing, tourism and ecotourism, health and pharmaceuticals, bio economy, biopharmaceuticals and bio-technologies conditions, restaurants, confectionery and pastry laboratories can be supplied with fresh, quality products and can help to revive the rural economy (Nicula V., Spânu Simona, 2019).

Also, at national level, the beekeeping program for the period 2017 - 2019 sets out a series of objectives aimed at: maintaining the health status of the bee families and treating them with products approved by the Institute for the control of biological products and medicines for veterinary use; the use in beehives of bees (queens) and bee families that lead to obtaining quality products, preferably that the beekeeping biological material comes from the Apis Mellifera Carpatica breed; encouraging the practice of pastoral beekeeping, by moving bee families to honeybee ponds to obtain greater honey production, to diversify bee products and implicitly to make beekeeping more efficient; the refurbishment of beehives, first of all through the acquisition of quality beehives, this element being subjected to excessive use due to the actions of loading - unloading repeated and the purchase of accessories and beekeeping equipment needed in the activity of beekeeping to improve the quality of bee products in order to make better use on market; market capitalization of honey production and bee products after conducting analyses regarding the authenticity of honey, geographical area of origin, detection of fraudulent practices, etc. (http://www.madr.ro/programul-national-apicol.html).

From the data provided by Apia Hunedoara, regarding the evolution of the number of applicants and the amount settled for the financial support granted to the beekeepers from Hunedoara County during the period 2007-2019, it results that the beekeepers from Hunedoara have accessed European and national funds, carrying out projects that have consolidated their business. The number of projects carried out in beekeeping in Hunedoara County has changed significantly, from 115 applications in 2012, to 41 in 2016 or 64 in 2018 (they asked for 262,039 lei). The European-funded programs of the past years have contributed to the development of the Hunedoara beekeeping industry. The number of bee families has increased to about 30,000 , ten thousand more than 20 years ago (Gupta R.K., 2014). The beekeepers' guild also increased, some of the new entrants managed to stay in production after the financing program was completed. However, the Romanian honey remains an ash on the range of priorities of the authorities.

The socio-economic factors contribute both directly and indirectly to the sustainable development of the beekeeping activity. The strategic planning process is based on the documentation on the existing situation, on an x-ray of the reality on the ground that will help to understand the needs of the community. This analysis is based on a broad methodological framework, based on quantitative, qualitative data and field analyses, including consultation with relevant local actors.

Hunedoara county comprises, from an administrative point of view, 14 cities out of which 7 municipalities and 55 communes with 457 villages (Jornea Eugenia, 2017). Three of the cities of Hunedoara County have a population of less than 10,000 inhabitants. With a stable population of 418,565 people at the 2011 census, Hunedoara County is noted at national level by the significant demographic decrease between the 2002 and 2011 censuses, registering among the 10 counties that registered a decrease in population over 
$12 \%$. The downward demographic trend continued after 2011, the reports of the Hunedoara County Statistics Department showing a continuous decrease of the population over the last 9 years. Hunedoara County ranks first nationally in terms of the percentage of stable population living in the urban area, respectively $75 \%$ at the 2011 census and $77.9 \%$ resident population in the urban area in 2018. A specific problem for Hunedoara County is in the small demographic mass of localities, both urban and rural.

The age pyramid indicates an aging population, respectively a small share of young people and a high share of adults and the elderly, Hunedoara County ranking last in the region in terms of population number in the 0-14 age group. This is the consequence of a low birth rate, with an obvious maturation and aging of the population, which contributes to the demographic vulnerability of the county. The tendency of the population decrease had inevitable consequences on the workforce in Hunedoara county, so that in 2017 the level of labour resources in the county decreased by more than $16 \%$ compared to the level of 2007 At the same time, the civilian active population decreased by more than $9 \%$, and the civilian active population decreased by $8.25 \%$.

The target group of organic bee products is represented by the preschool and school population up to the level of secondary school, which can benefit from healthy honey from a safe, certified source and from a local source. Neither is the school population in high schools eligible for awareness and food education courses on the benefits of honey. Thus, at least two coordinates are reached, namely the education of the young generation for a healthy diet and the promotion of a local activity that contributes to increasing the interest for developing some business in beekeeping and marketing honey.

The analysis of the educational offer, the demand and the projection of the potential demand on areas of high school education in Hunedoara County, indicates the increased interest of the students towards the specializations in the field of trade, mechanics, tourism and food and the economic field. Thus, the young population tends to focus on areas with a wider openness, compared to the strong industrial profile of the county. At the opposite end, the field of agriculture, although supported in the Local Action Plan for Education 2013-2020, unfortunately does not arouse the interest of young people.

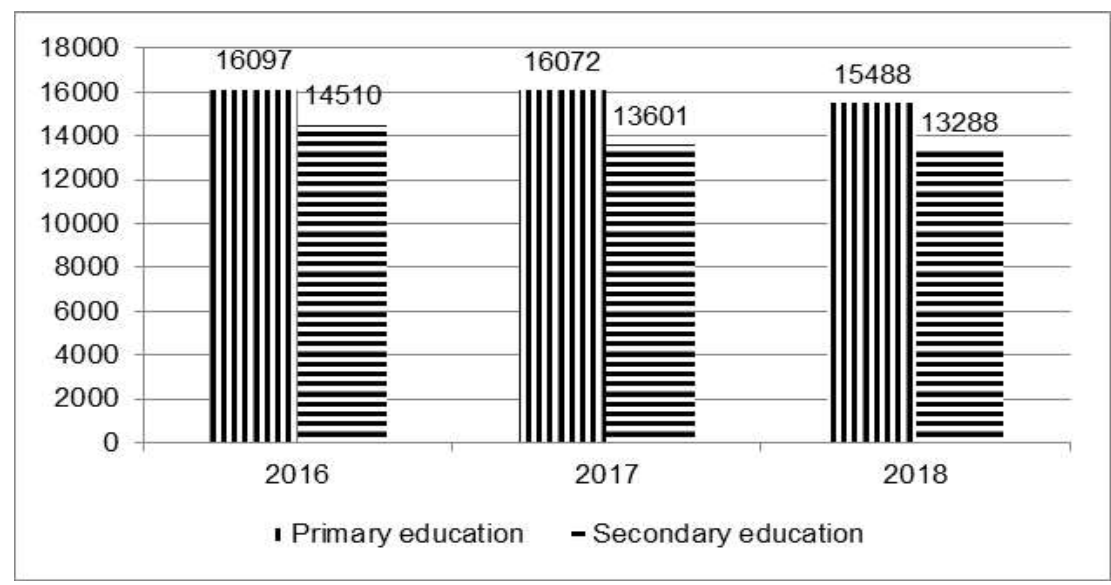

Fig. 2 Evolution of the school population from primary and secondary education, in Hunedoara County during the period 2016-2018 (no. of persons)

Source: insse.ro processed data 
A consequence of the negative economic dynamics of Hunedoara County is the high unemployment rate, constantly above the national average (in 2018 this indicator registered a value of $3.4 \%$ in Hunedoara County, compared to $1.8 \%$ at the level of the Western Development Region. In the county territory there are "nuclei" of unemployment concentration, located especially in mining areas or in communes located at great distances from the main communication routes and from the locations of concentration of recent investments. Most of the land fund in Hunedoara County is privately owned (agricultural land fund being owned by private owners in proportion of over 98\%), the main requests for relocations referring to forest land (APIA Report, 2018). Regarding agriculture, we notice a relatively constant value of agricultural production, with fluctuations influenced by the vegetal production depending on the weather conditions. From the point of view of vegetable production, the main crops are potato and maize for grains (the largest cultivated areas and the highest production), and the fruit production has a growth tendency. In Hunedoara County, the amount of pesticides administered on private property areas is very small, which is why beekeepers benefit from spontaneous flora and crops under an ecological regime. Hunedoara beekeepers, who choose to go with the hives in the pastoral, must know the situation of pesticide administration on the cultivated areas where they place their hives. As the preferred pastoral areas are either in the western plains of the country, in Banat or in the southwest of the Romanian Plain, it is necessary to mark with indicators the areas where pesticides have been applied in order for the beehives to be located at great distances from these areas (https://www.green-report.ro).

The constant increase of the incomes per household emphasizes the importance of the activities carried out in agriculture, implicitly the possibility of increasing them through beekeeping. Honey is not only for the own consumption of those who practice beekeeping, but also allows an increase of the income per household, especially when it is produced under the conditions required by the ecological certification. Hunedoara County has a high potential for practicing this activity, which is why over 1000 beekeepers are registered in the profile associations, 300 of them having the ecological certification of the bee products obtained.

In the county of Hunedoara the services with low added value prevail ( $92 \%$ of the turnover registered in the services sector). Of these, the most important is the wholesale and retail trade, which accounts for $67 \%$ of the turnover of the sector, indicating a reduced diversification of services at county level. It is followed by land transport and storage, water distribution, sanitation, waste and tourism, all being low value-added services. At the County level, market services that incorporate a high degree of knowledge and which have a higher share are architecture and engineering and real estate transactions, landscape, renting and leasing.

Tourism has potential for growth at county level, a fact illustrated both by the increase in demand for tourist services (number of visitors, number of overnight stays, etc.), as well as the interest of local actors for this area. Rural tourism and agro-tourism represent a viable possibility of sustainable local development, supported by a special natural heritage, by multicultural gastronomy and by the traditions and customs of the village communities, preservers of this treasure. 
The analysis of the number of reception structures with accommodation function and the number of tourist arrivals from Hunedoara County, by types of structures (20162018) reveals the following:

- in 2017 most arrivals were registered in hotels: Geoagiu with 44,182 persons, Deva30,236, Hunedoara - 19,069, Petroșani- 10160 persons; in pensions: Petroșani with 365 people, Lupen- 3,850, Brad with 2490; in agritourism pensions: 1,505 persons in Râu de Mori, 770 tourists in Orăștioara de Sus, Dobra with 782 persons and so on.

- the number of tourist reception structures with accommodation function remained relatively constant during the analyzed period: most hotels are in Geoagiu (7), Petroșani (5), Deva (4); tourist cottages Lupeni (12), Petroșani (10); tourist pensions in Lupeni (21 compared to 8 in 2016), Hațeg (13 compared to 7 units in 2016); agro tourism pensions in Râu de Mori (5 in 2018 compared to 2 in 2016), Șoimuș (4), Orăștioara de Sus (3 units in 2018 compared to one in 2016), Dobra (2) and so on.

Following the analysis of the number of tourist nights in the reception structures in Hunedoara county, by types of structures, at the level of 2017 most nights were registered in hotels: Geoagiu with 147,919, Deva with 46,910, Hunedoara with 26,783, Petroșani with 16,352; in pensions: Petrosani with 5,840, Lupeni with 5,078, Brad with 4445; in agro tourism pensions: 4,218 in Râu de Mori, 1,019 in Orăștioara de Sus, Dobra with 937 etc. It is obvious that the lack of total or partial data, as the case may be, makes a relevant analysis on the Hunedoara tourism sector difficult. It is also surprising the small number of tourists staying in the county, given the unique tourist objectives in the country and even in the world (Corvin Castle in Hunedoara, Dinosaur Geopark in Hațeg Country, Deva Fortress and Sarmisegetusa et al.). The poor promotion and the lack of actors from the tourism of Hunedoara at the profile fairs can be one of the explanations, which unfortunately add the insufficient network of the accommodation units.

The public supply units are much more numerous, their development being related to the existence of mining cities. At the level of 2019, most classic restaurants are in Lupeni (25), Hunedoara (9), Deva (7), Hațeg (7), Orăștie (7), Geoagiu Bai (6), Straja (5), Vața de Jos (3). Family restaurants or boarding houses have been developed in the areas where rural tourism and agro tourism are practiced: Râu de Mori (8), Hațeg (5), Orăștioara de Sus (4). Day bars are more numerous in cities or resorts: Deva (6), Geoagiu Băi (6), Hunedoara (5), Lupeni (4), Orăștie (3), Petroșani (3) and so on. These units selected at county level sell honey for specific products, and may become future customers of the beekeeping associations or partnerships created within the proposed short distribution chain. In the context of the decline of industrial activities, especially those related to mining, the county has begun the process of reconfiguring the economy, relying more and more on tourism. This fact is visible also in the increase of the tourist offer in the last years and especially in the number of tourist arrivals. Providing from these favourable tendencies, the county tourism needs an additional impulse from promoting a strong local identity, relying on the characteristic ethnographic areas and (re)qualifying the labour force to the trades that support the tourist activities.

The technological factors are particularly important in order to increase the economic competitiveness of the beekeeping sector. Between 2010 and 2014, there was a positive entrepreneurial dynamic in Hunedoara County, in the sense that, beyond the 
variations from year to year, the number of newly created companies was constantly higher than those cancelled. The sectors that have registered significant percentage increases in the number of enterprises are: agriculture, forestry and fishing (they saw an increase in the reference period by $117 \%$ ). The economic domains and sectors identified as potential drivers for the development of Hunedoara County are (in descending order): tourism (hotels, restaurants); agriculture, forestry/energy production; recreational, artistic and cultural activities. The establishment of high profile companies, the development of bee-growing activities and the exploitation of the related raw materials are based on the increasing tendency of consumers to purchase health-beneficial products. Thus, it is encouraged to diversify the product offer, to modernize the technology used, to trade online and to look for opportunities to market bee products abroad.

Legislation and regulations of a legislative nature support local producers and contribute to supporting sustainable development through environmentally friendly activities. At European level, there are a series of legislative acts regulating the activity of supporting bee producers and marketing of bee products. The national legislation, harmonized with the European legislation, brings a series of completions regarding the activities carried out by associations or natural persons regarding the obtaining and marketing of honey and bee products.

Ecological (environmental) factors show oscillations that can cause marked changes in the physiological processes of plants, bees or in the production and harvesting of honey. Food with an exceptional nutritional value, honey is a biological product that is closely related to the state of the weather. Few people know that the taste, aroma and quantity of honey produced by a family of bees depend on the weather. The nectar secretion of honey plants and its harvest by bees depend directly or indirectly on the evolution and weather conditions.

It is a well-known fact that, in addition to the evolution of the time, the abundance of honeycomb and the power of the bee family play a decisive role in honey production. No matter how great the nectariferous potential of honey plants and how good the biological status of the bee family is, if unfavourable weather conditions occur during flowering and harvesting, such as: low temperatures during the day, continuous rain, storms, the flight of the bees is hampered and the harvest, respectively the production of honey is partially or totally disastrous. Therefore, the knowledge of the atmospheric conditions as a factor that influences the picking in beekeeping and to identify the specific environmental challenges (Ogrean Claudia, 2015) allows the judicious choice of the massive honeycombs and the rational management of the pastoral carving, thus avoiding unnecessary trips. Insects are the most varied and abundant animals, being essential for the proper functioning of all ecosystems. It is worrying that over $40 \%$ of insect species are in decline and one third are in danger of extinction, the extinction rate being eight times higher than in mammals, birds and reptiles. The total mass of insects decreases by $2.5 \%$ per year, suggesting that they may disappear within a century (https://www.green-report.ro). Intensive farming, especially the use of pesticides, is the main cause of the decline of insects. Urbanization and climate change also have a major impact on insects. Bees have also been severely affected in many parts of the world, partly because of the use of pesticides. Romania still benefits from biodiversity and depends on the measures taken to preserve it. 


\section{Organic bee products}

By definition, honey is a completely natural product, which contains neither additives nor preservatives. The date indicated on the labels is an indication of freshness, but the honey can be preserved for a long time, retaining its original taste and taste. According to European law, the simple word "honey" on the packaging is sufficient to assure the consumer that the product is $100 \%$ natural. The ecologically certified bee products are marketed, both on the internal and external market.

In order to avoid the placing on the market of products of doubtful nutritional value, that represents one of the key concepts in strategic management (Ogrean Claudia, 2016) and authenticity, bee products and honey, in particular, should be accompanied by analysis bulletins and appropriate labels, which contain the information needed to recognize the type of honey, the producer and of the main constituents of the chemical composition. The organic honey manufacturer has the right to use the bio label for all its products, as a welldeserved recognition of the quality of these products and of the efforts made to provide the customer with healthy and tasty foods. Naturally, this also means better prices and a guaranteed sale, especially when it comes to wholesale. Demand on the bio market is increasing in modern society, and the trend will accentuate in the future. Of the 12,249 tonnes of organic honey exported in 2017 , most were sold, outside the EU countries, to Japan. The main destination remains the EU, with $80 \%$ of the exported quantity: Germany with $38 \%$, Italy with $19 \%$ and France with $8 \%$.

The evolution of the organic beekeeping sector in Romania has seen an upward trend in recent years, with an increasing number of certified organic beekeepers, due to the increased demand for organic products on the European Union market, as a result of increasing consumer confidence in the products certified ecologically (Hall J.K., Daneke G.A., Lenox M.J., 2010). The Community and national financial support for the beekeeping sector is granted according to the National Apiculture Program developed by the Ministry of Agriculture and Rural Development together with representatives of the professional beekeeping organizations, for the period 2017-2020 and aims at improving the conditions of production and marketing of bee products, in the conditions in which the image-brand, logos, brings a durable and distinctive competitive advantage (Herciu Mihaela, 2015).

According to the data available in the APIA Report for 2018, the total amount authorized for payment in 2017 was 32.5 million lei for a number of 4544 payment requests. In Romania, organic beekeeping is a dynamic sector. The first certified producers in organic beekeeping were registered in 2000 . The number of producers in this sector increased every year, so in 2005 there were 132 certified producers in organic beekeeping; in 2006 - 336 processors and 2 exporters; in 2008 - 584 producers, 15 processors, 22 traders, 1 importer and 8 exporters; in 2011 there were 912 registered organic beekeepers, with a number of 97,997 bee families; in 2017, in Romania, 371 beekeepers were certified ecologically or in the conversion stage, owning 58,912 bee colonies (ROMAPIS, 2017); at present this number has dropped to about one third of the original one. Organic beekeeping farms include both individual beekeepers and a number of associations in beekeeping. Honey and bee products from organic farming also have 
significant achievements. Thus, in 2008 over $65 \%$ of the ecological honey was destined for export, an amount of 1,100 tons being exported to the EU markets.

Currently, functional partnerships can be developed between a micro-enterprise specialized in organizing events and promotion, tourist pensions that provide food services, public food units that are located in an area with good commercial ford and local beekeeping producers in HNV areas, of which at least one holds the certification of organic honey. Honey and bee products from local beekeeping producers have been marketed so far in the fairs and markets of Hunedoara and in the neighbouring villages of Pestișu Mare commune, but also directly to individuals. For these beekeepers, the clients of individuals are now an overwhelming share of buyers. The profile of these clients has the following characteristics: they live in the environment and have no relatives in the rural area or, if they live in the rural area, they do not have producers of bee products in the area of the commune of residence. Most clients are in the 26-64 age group (65\%), followed by those over 55 (20\%) and, finally, those under 25 (15\%). Clients have average and above average incomes and are either young people, interested in leading a healthy lifestyle and as close to nature as possible, whether they are families with young children or people with special dietary needs (diet, detoxification, certain conditions). Some of the customers are people interested in the taste of the products, elderly people who want to find the products and taste of childhood, residents of big cities visited relatives, tourists and practitioners of performance sports. Regarding the legal persons, the main categories of clients are represented by the companies in the field of HORECA (restaurants, tourist and agrotourism pensions, bars, cafes) who purchase both packaged honey to serve with the marketed teas, as well as bulk and jar honey, for use in the preparation of pastry/confectionery products. In addition, a segment of customers is represented by the confectioners / confectioners, who mainly buy honey in the jar and bulk, to use it in the composition of the different types of desserts made. Local companies and companies often buy gift packages offered to their employees, and cosmetic laboratories and salons mainly buy bee products (apricot, propolis, beeswax) that they use in the preparation of creams, lotions and masks cosmetics. Sports associations and clubs, parents' associations, the management of schools, kindergartens, day centers and asylums for the elderly purchase honey and bee products for the added energy and vitamins they offer, but also as a healthy alternative to other types of sweets.

In order to dispose of bee products (honey, organic honey, pollen, propolis, etc.) in optimal conditions, to be marketed, a short chain created from a specialized microenterprise, tourist pensions providing food services and restaurants is proposed or bars that are located in a good commercial area, local beekeeping producers in HNV areas, of which at least one holds organic honey certification.

Table 2: Estimated annual revenues from the sale of bee products from partners who are part of the short supply chain

\begin{tabular}{|l|l|l|r|r|}
\hline \multicolumn{1}{|c|}{ Product } & Quantity & Price $/ \mathrm{kg}$ & \multicolumn{1}{c|}{ Annual revenue (lei) } & Annual revenue (euro) \\
\hline Conventional honey & $2000 \mathrm{~kg}$ & $15 \mathrm{lei} 8 \mathrm{~kg}$ & 30000 lei & $6522 €$ \\
\hline Organic honey & $1000 \mathrm{~kg}$ & $20 \mathrm{lei} / \mathrm{kg}$ & 20000 lei & $4348 €$ \\
\hline Pollen & $100 \mathrm{~kg}$ & $30 \mathrm{lei} / \mathrm{kg}$ & 3000 lei & $652 €$ \\
\hline Propolis & $17,5 \mathrm{~kg}$ & $200 \mathrm{lei} / \mathrm{kg}$ & 3500 lei & $761 €$ \\
\hline Total & 56500 lei & $12283 €$ \\
\hline
\end{tabular}


Creating an operationalized short supply chain allows beekeepers within a partnership to market annually 2 tonnes of conventional honey, 1 ton of organic honey, 85 kilograms of pollen and 15 kilos of propolis convenient and safe to deploy their products, which will motivate them to produce more, invest in the growth of bees and provide the highest quality products, which in the future will be able to certify eco or to obtain a trademark certificate. Given that, currently, beekeepers who wish to implement this type of partnership have a certain production capacity (conventional honey 1.5-2 tonnes / year; organic honey 1 ton / year; and bee products (about $100 \mathrm{~kg} /$ year), we estimate that in the next years after the implementation of the business sales will increase and, implicitly, they will increase revenues from the marketing of honey and bee products.

The average annual revenues estimated for the short honey marketing chain are about 12,000 euros/year, with the possibility that this amount will increase from year to year. The forecast of incomes over the next 5 years implies a constant and sustainable growth.

Table 3: Estimated revenues from the sale of bee products through the short chain for 5 years

\begin{tabular}{|l|c|c|c|c|c|c|}
\hline Year & Year I & Year II & Year III & Year IV & Year V \\
\hline $\begin{array}{l}\text { Estimated revenue for the } \\
\text { producer group }\end{array}$ & $12283 €$ & $13500 €$ & $15000 €$ & $16500 €$ & $18000 €$ \\
\hline
\end{tabular}

As the product goes through its life cycle, demand and competition conditions tend to change. Usually, the price is set at a high level during the launch stage for two reasons: the high attractiveness and the desire of the manufacturer to recover its costs as soon as possible. Subsequently, the price strategy depends on the elasticity of demand. If the demand is non-elastic, a high price is kept. If the demand is elastic, it is preferable to align at or slightly below the market price. During the growth and maturity stages of the product, prices usually fall due to increased competition. It also increases the supply of products and extends the target market to categories of buyers with lower incomes, so the price must be adapted.

The advantages of the short chain are multiple, both for efficiency, for eliminating the costs generated by intermediaries, and for the traceability of the products, their provenance being traceable, and the quality being thoroughly verified and eco-certified for the products that fall into this category.

The beekeeping sector requires a coordinated collaboration between beekeepers and economic operators working in the field, in order to increase communication and provide support in the process of opening new companies.

The short chain meets all the attributes of a SMART project because it is:

- Specific: it provides detailed information about the characteristics of honey and bee products that we offer to potential customers, about the health benefits of honey consumption;

- Measurable: presents quantitative and qualitative aspects of honey and bee products to be marketed, but also regarding the number of potential beneficiaries of the activities carried out; 
- Accessible: The objectives of the project of setting up a short distribution chain can be really achieved with the capacity and resources available.

- Relevant: the achievement of the objectives contributes to the targeted impact, to market traditional and innovative bee products, in order to contribute to the education and awareness of customers about the benefits of honey for the health of the body and to empower potential clients to participate in the sustainable development of to the rural area of Hunedoara by purchasing local products;

- Classified in Time: the calendar of activities is carried out for a fixed period (for example 10 months), during which there will be promotional events within selected pensions and restaurants, advertising, participation in profile fairs and so on.

\section{Conclusions}

The creation of a bee micro-enterprise with a competitive and sustainable activity requires the elaboration of a strategy of vitalization and transformation of the beekeeping sector by discovering market opportunities and promoting diversified and quality products. Beekeeping entrepreneurship can be developed through the actions of beekeepers in the field of promotion, by efficiently selecting possible distribution channels in the country and abroad, quality control of bee products, conversion to organic beekeeping, use of personalized packaging and product labelling.

Entrepreneurship in the beekeeping sector is generating benefits, having social value (creating collaborative relationships between beekeepers), economic value (increasing beekeepers' income) and value for the environment (as a determinant of sustainable development through biodiversity conservation). Beekeeping not only directly influences the quality of life, but also indirectly through its interference with some branches (agriculture, industry, trade). Thus, through tourism and on-line commerce, local products are valued in a superior way, stimulate the production of honey and bee products with an important role in ensuring the quality of life, and contribute to the development of competition, which leads to the improvement of quality standards for the benefit of consumers.

The PESTEL analysis shows that the development of beekeeping and the marketing of bee products engage a plurality of components with stimulating and entrainment effects, both in the sphere of honey production and other related branches of activity, which stimulate the trial of economic increase and allow sustainable rural development.

\section{References:}

Bogdanov S., (2009), Honey Trade, Bee Product Science

Borza Anca, Mitra Cătălina, Bordean O., Mureşan Anamaria, Supuran Roxana, 2009, Antreprenoriat. Managementul firmelor mici şi mijlocii, Ed. Risoprint, Cluj-Napoca.

Bradbear N., (2003), Beekeeping and Sustainable Livelihoods, Food and Agriculture Organization of the United Nations, Rome 


\section{Studies in Business and Economics no. 15(1)/2020}

Conrad R., (2013), Natural Beekeeping - Organic Approaches to Modern Apiculture, Chelsea Green Publishing

Coughlan A. T., Anderson E., Stern L. W., El-Ansary A. I., (2005), Marketing Channels. New Delhi: Prentice-Hall of India Private Ltd.

Gupta R., K., Reybroeck W., van Veen J.W., Gupta A., (2014), Beekeeping for poverty alleviation and livelihood security, Springer Nature

Hall J.K., Daneke G.A., Lenox M.J., 2010, Sustainable development and entrepreneurship: Past contributions and future directions, Journal of Business Venturing 25:439-448.

Herciu Mihaela, (2015), Challenges for Business Competitiveness from Managerial and Knowledge Economy Perspectives, Studies in Busines and Economics, Sciendo Publisher, vol. 10, pp.3240

Ignjatijević Svetlana, Milojević I., Andžić Rosa, (2018), Economic analysis of exporting Serbian honey, International Food and Agribusiness Managemsent Review, 2018

Jornea Eugenia, Lupu-Dima L., Edelhauser E., (2017), GIS, integrated solution, for efficient administration of Hunedoara County, MATEC Web of Conferences

Napolitano G., (2006), New Design in the Honey Agribusiness (the case "Mieles naturales de la bahia - MR"). World Food And Agribusiness Symposium, Buenos Aires, Argentina, International Food \& Agribusiness Management Association

Nicolae Simona, (2010), The Knowledge Based Society - Myth or Reality for Romania?, Communications of the IBIMA

Nicula V., Spânu Simona, (2019), PESTEL analysis applied in tourism evaluation in Brăila County, Revista Economică 71:3, available to http://economice.ulbsibiu.ro/revista. economica/archive/71304nicula\&spanu.pdf

Ogrean Claudia, (2016), The Valences of "Value" for the Strategic Management Process, Studies in Business and Economics, Sciendo Publisher, vol. 11, pp.88-96

Ogrean Claudia, (2015), Corporate Initiatives and Strategies to Meet the Environmental Challenges Contributions Towards a Green Economic Development, Studies in Business and Economics, Sciendo Publisher, vol. 10, pp.62-70

Qaiser T., Ali M., Taj S., (2013), Impact Assessment of Beekeeping in Sustainable Rural Livelihood, Journal of Social Sciences, COES\&RJ-JSS, 2(2), 82-90.

Purnhagen K., Wesseler J., (2016), "Chapter 13 The "Honey" Judgment of Bablok and Others Versus Freistaat Bayern in the Court of Justice of the European Union: Implications for Coexistence", Springer Science and Business Media LLC

Ramadani V., Hisrich R.D., Dana L.P., Palalic L., Panthi L., (2019), Beekeeping as a family artisan entrepreneurship business, International Journal of Entrepreneurial Behavior \& Research

***, (2014), Research Institute of Organic Agriculture FiBL and International Federation of Organic Agriculture Movements (IFOAM), The World of Organic Agriculture

***, (2018), APIA Report

***, (2019), MADR Activity Report

http://www.afir.info

http://ec.europa.eu/agriculture/honey/index_ro.htm

http://www.madr.ro/programul-national-apicol.html

http://apimondia.com/documents/apimondia newsletter en 6.pdf 